\title{
The Right Concept of Countries in the Implementation of Land Procurement for Toll Road Development
}

\author{
Diyan Isnaeni Sri Setiadji Suhariningsih \\ Faculty of Law, Universitas 17 Agustus 1945 Surabaya
}

\begin{abstract}
Since the start of rapid economic development in the new order era until now, the need for land has also increased. Land becomes an object of high economic value and is needed to support the smooth development of the country. One of the issues of concern in the land sector is the issue of land acquisition for toll road construction. The problems faced by the government in the implementation of land acquisition for toll road construction include the problem of providing land for the construction of the toll road itself, because state land which is directly controlled by the state is limited or can be said to be almost nothing anymore. The problem needs to be analyzed is how the concept of the right to control the state in the acquisition of land for toll road construction. The right of the state to control essentially authorizes the state to: regulate and administer the designation, use, supply and maintenance of earth, water, space and natural resources which contained therein is regulated in article 2 of Basic Regulations on Agrarian Principles Number 5 of 1960 and one of the manifestations of such authority is the establishment of Act No. 2 of 2012 concerning Land Procurement for development in the public interest. Philosophically, the concept of state control rights regulated in article 33 of the 1945 Constitution of the Republic of Indonesia is in line with the purpose of land acquisition for toll road construction, which is used for the greatest prosperity of the people. provide equitable access to the people, including customary law communities (MHA) in the implementation of land acquisition, especially in the provision of compensation for land taken for toll road construction.
\end{abstract}

Keywords: State's right to control, land acquisition

DOI: $10.7176 / \mathrm{JLPG} / 89-02$

Publication date:September $30^{\text {th }} 2019$

\section{A. Background}

Development in the public interest is one of the legal bases for the government in the context of carrying out land acquisition, because the government requires land to realize development in all fields but land availability is increasingly limited, thus land acquisition is hampered, and impacts on development implementation so that it cannot be carried out appropriately time according to the schedule that has been set

The limited land does not mean that land is not available, but land that is needed by the government turns out to have been controlled or owned by various legal entities, both private and public, such as government asset land, forest area land, and lands that have been owned or controlled by the community.

Since the start of rapid economic development in the new order era until now, the need for land has also increased. Land becomes an object of high economic value and is needed to support the smooth development of the country. One of the issues of concern in the land sector is the issue of land acquisition for toll road construction.

Fulfillment the need for land requires a right that gives great authority to the government to plan the designation and use of the person concerned for his business needs in order to improve the welfare of the community. and prosperity evenly for all Indonesian people. Referring to the rights of the state, the constitutional authority as stated in Article 33 of the Constitution of the Republic of Indonesia (hereinafter abbreviated as the 1945 Constitution) becomes an obligation and responsibility for the state so that welfare, justice and prosperity (general welfare) can realize one of the objectives Country.

Problems faced by the government in the implementation of land acquisition for toll road construction include the problem of providing land for the construction of the toll road itself, because state land which is directly controlled by the state is limited or can be said to be almost non-existent. The only way that can be taken is to free up people's land, both controlled by customary law, and other rights attached to it.

Act Number 38 of 2004 concerning Roads Article 1 number 7 and 8 stipulates that toll roads are public roads that are part of the road network system and as national roads whose use is required to pay for tolls, while what is meant by tolls is a certain amount of money paid for toll road use.

Toll road development is one type of development in the public interest, as a consequence of the nomenclature of development in the public interest, the construction of toll roads must be carried out through a land acquisition mechanism, therefore the smooth process of land acquisition will affect the smooth development

${ }^{1}$ Sri Setiadji, Hak Menguasai dan Pengelolaan SDA dalam Perspektif Sistm Perekonomian, Opini, Radjawarta, Minggu 24 September 2018. 
of the toll road.

Based on the above background, what we want to discuss in this paper is how is the concept of state control over land acquisition for toll road development?

\section{A. Discussion}

\section{Nature of the Right to Control the State on Land.}

The state's right to control essentially authorizes the state to: regulate and administer the allocation, use, supply and maintenance of the earth, water, space and natural resources contained therein. This authority is regulated in article 2 of Law Number 5 of 1960 concerning Basic Regulations on Agrarian Principles (hereinafter referred to as UUPA), State Gazette, 1960-104, Supplement to State Gazette 2043 and one form of such authority is the establishment of Law Number 22012 concerning Land Procurement for Development in the Public Interest.

The Act Number 2 of 2012 is a legal basis for the government to take land for public purposes, which regulates the types of development activities for toll road construction. Land acquisition mechanisms are often used and most cause problems both legally and empirically, because the current development implementation, besides improving the welfare of the community turned out to cause problems.

The right to control the State is appointed and developed from the provisions of Article 33 paragraph (3) of the 1945 Constitution of the Republic of Indonesia, which in the UUPA is placed in Article 2 with the following formulation:

(1) On the basis of the provisions in Article 33 paragraph (3) of the 1945 Constitution and the matters referred to in this article, the earth, water and space, including the natural resources contained therein, are at the highest level controlled by the state as an organization of power for all people.

(2) The controlling right of the state referred to in paragraph (1) of this article authorizes:

a. regulate and administer the designation, use, supply and maintenance of the earth, water and space;

b. determine and regulate legal relations between people and the earth, water and space;

c. determine and regulate legal relationships between people and legal actions concerning earth, water and space.

(3) The authority derived from the state's right to control in paragraph (2) of this Article is used to achieve the greatest prosperity of the people, in the sense of happiness, prosperity and independence in the Indonesian society and legal state that is independent, sovereign, just, and prosperous.

(4) The exercise of control over the state mentioned above can be exercised in the authority of the autonomous regions and customary law communities, merely required and not in conflict with national interests, according to the provisions of Government Regulations."

The right to control the state (hereinafter abbreviated as HMN) according to the 1945 Constitution must be seen in the context of the rights and obligations of the state as the public (domein) which is publiekrechtelijk, not as eigenaar which is privaaterechtelik.

As clearly stated the purpose of the right to control the state for the greatest prosperity of the people. It can also be said that the UUPA provides an attitude to achieve the objectives of Article 33 paragraph (3) of the 1945 Constitution out of place, if the state acts as the owner of the land. According to the UUPA's explanation, the state as an organization of power of all people is indeed not the owner, but acts as a ruling body which at the highest level controls the earth, water, space, and natural resources contained therein. It is more appropriate if the state as an organization of power of the whole people (nation) acts as the ruler who is given the authority to at the highest level carry out the authority, as mentioned in Article 2 paragraph (2) of the UUPA.

The concept of the right to control the state according to the 1945 Constitution of the Republic of Indonesia must be seen in the context of the rights and obligations of the state as the owner of power who has the task of creating people's welfare. The position of the state as the ruling body of the owner of power is the embodiment of the ideology of the relationship between individuals and the community in the conception of customary law whose crystallization of values is formulated in the Preamble of the 1945 Constitution of the Republic of Indonesia, so that the right to control the state contains within it to carry out its rights and obligations which give birth to power, authority even forced power.

The state's authority to regulate, administer and supervise land rights in individuals, communities and the state is closely related to the concept of a balance between rights and obligations which contains elements that every right has an obligation in it, and vice versa.

The meaning of the right to control the state is the state's demands on individuals, communities and the state itself to exercise rights in accordance with the obligations imposed on it in the form of utilizing land, protecting and guaranteeing the rights of others and preventing actions that cause other parties to lose opportunities or land rights.

The basic structure of the land tenure relationship between individuals, communities and the state mentioned above is believed to be the basis that will bring the Indonesian people to glory in the future. Therefore the state as an organization of national power and its position as a ruling body in carrying out the functions of 
regulating, managing and supervising in it contains the substance of achieving the greatest prosperity of the people. Without such state power it is impossible for people's welfare related to land to be achieved. However, state power must also be carried out in accordance with the principles contained in the mindset of opening the 1945 Constitution of the Republic of Indonesia, the constitution and the applicable laws and regulations so that the attitude of the state acts through its government not only has legitimate legitimacy but also in accordance with the stages expected welfare development.

\section{Land Procurement for Toll Road Construction}

The right of control of land is essentially a reflection of the human view of him as a human being in relation to the land. Human relations with the land give birth to authority and responsibility for the prosperity of oneself and others. Land tenure is a right that is only possible if the person or legal entity that will have the right is legally competent to claim the object to which is his right.

On the other hand humans have the need for good legal regulations. Good, not in the context of right-wrong, but efficient, and effective. Efficient in this case means that it is right on target and appropriate in practice. Effective means that the practice of law is able to run in line with other human social activities. With a law like this will have an impact on improvements that bring all the benefits as a result. Human desire for law like this becomes a necessity, and is said to be scarce. ${ }^{1}$

The existence of land acquisition legal institutions is sourced from the concept of national land law derived from customary law, namely religious communalism. This conception allows individual land tenure, with rights to land that are personal, at the same time contain an element of togetherness. From this conception was born the concept of social functions of land rights in Article 6 of the UUPA.

Based on the concept of social function, the principle of respect for land rights is elaborated. This principle must be upheld in order to create a balance of individual and community interests. The concept of national land law is concretized in the legal principles that underlie the acquisition of land in the public interest. The law itself is not a mirror of justice and ethics, therefore the law must be released from ethics. The law must be separated from the values of "good or bad", "right or wrong", or "fair or unfair". It does not matter, whether the law is fair or not, the important thing is "sovereign commandment", then that is the real law and everyone is asked to obey it. Law also does not come from the soul of society, but law comes from sovereign orders. Therefore, the law exists because of the command of a sovereign ruler. ${ }^{2}$

Land acquisition for public purposes, one of which is the construction of toll roads is one part of land management in Indonesia. It has some strategic elements that are very important to be examined further, rather than the 'land acquisition process', that is:

First, land acquisition for toll road construction is related to the progress or improvement of development, in this case the construction of infrastructure facilities and projects aimed at providing large benefits to the public and financially high value. Any difficulties in land acquisition, both in regulations and implementation practices, will impact on the obstruction of infrastructure development projects, and in the end result in the benefits of infrastructure facilities that cannot be immediately felt by the general public. This will certainly hamper development goals for the benefit of the community.

Second, the process of land acquisition for toll road construction is related to the issue of the release and termination of land rights and objects on land from their owners. This will also relate to the life of the owner of the rights to the land and objects on it which are basically human rights. The element of releasing land for development in the public interest by the owner of the rights, of course, will be different from the release of land rights which are the will of the owner of the rights if he really intends to relinquish his rights in a free transaction

The construction of the toll road is carried out for the smooth transportation of people, goods and services that are the livelihood of many people, so that even though it cannot be freely accessed by the poor, but with the toll road, both the direct and indirect benefits will be felt to meet the needs the whole community. Not all facilities for public use can be fulfilled by the state, due to the increasing needs or demands of the community.

As a positive law or currently in force in relation to land acquisition for toll road construction is Act number 2 of 2012 concerning Land Procurement for Development in the Public Interest. The provisions of Article 1 number 2 defines land acquisition as follows: "Land acquisition is the activity of providing land by giving appropriate and fair compensation to the right party." The party entitled to is the party who controls or owns the object of land acquisition. Object of Land Acquisition is land, space above ground and underground, buildings and plants, objects related to land, or other that can be valued.

\footnotetext{
${ }^{1}$ Fajar Sugianto, Efisiensi Ekonomi Sebagai Remedy Hukum, DIH, Jurnal Ilmu Hukum Februari 2013, Vol. 9, No. 18, p. 92.

${ }^{2}$ Syofyan Hadi, Hukum Posotif dan The Living Law(Eksistensi dan Keberlakuannya dalam Masyarakat) DiH Jurnal Ilmu Hukum Volume 13 Nomor 26 Agustus 2017, p. 261.

${ }^{3}$ Tine Suartina, Analisis Hukum Pada Kebijakan Kebjakan Pembebasan Tanah Untuk Kepentingan Umum di Indonesia, Jurnal Masyarakat \& Budaya, Volume 10 No. 1 Tahun 2008, p. 151-153.
} 
Regarding positive law, there is an opinion that equates current legal terminology with positive legal terminology, which is an incorrect opinion, because positive law does not always apply at the moment, but on the contrary the current law in it does not only consist of positive law (the law established by the competent authority), but also includes the law that is not positivated (determined by the authorized authority), for example customary law (adat recht), customary law. ${ }^{1}$

The formation of Law Number 2 of 2012 which regulates one type of public interest, namely development activities for toll roads as stipulated in article $10 \mathrm{~b}$, is inseparable from the legal politics that existed at the time the law was drafted. In connection with politics and law according to Bentham in his book Introduction to the Principles of Morals Legislations (1789), cited by Fajar Sugianto argues that good political and legal theory and practice can be reconstructed from the first principle, namely to spread happiness through the extension of law . The creation of the right law will lead to happiness by reasoning from the first principle above rather than adopting a pile of ancient authority that is no longer valuable. ${ }^{2}$

The Act No. 2 of 2012 in conjunction with Presidential Regulation No. 71 of 2012 stipulates that land acquisition for public purposes is carried out by the National Land Agency of the Republic of Indonesia (now the Minister of Agrarian Affairs and Spatial Planning/Head of the Republic of Indonesia's National Land Agency). The implementation of land acquisition for public use is carried out by the Head of the Regional Office of the Provincial National Land Agency. By considering efficiency, effectiveness, geographical conditions, and human resources, the Head of the Regional Office of the Provincial National Land Agency can assign it to the Head of the District/City Land Office as the Chair of the Land Acquisition Officer (PPT). Acquisition of land in the acquisition of land for public use is carried out through consultation between the Land Acquisition Officer (hereinafter abbreviated as PPT) and the party entitled to include agencies that require land.

The deliberation agenda is to determine the form and amount of compensation. The definition of compensation is stated in Article 1 number 10 of Law No. 2 of 2012 juncto Article 1 number 10 of the Republic of Indonesia's Presidential Regulation No. 71 of 2012, is an appropriate and fair replacement to the party entitled to the land acquisition process. .In the process of providing compensation must be considered the principle of balance

Provision of compensation for land acquisition for public purposes according to Article 33 of Law No. 2 of 2012 in conjunction with Article 65 of Presidential Regulation Number. 71 of 2012, are: land; basement and basement; building; plant; objects related to land; and / or other losses that can be valued.

\section{The Concept of State's Right to Control in Land Procurement for Toll Road Development}

Toll road construction is a form of government effort to facilitate the people in Indonesia to be able to carry out their mobility both in the economic and social fields well and quickly. Large-scale development such as the construction of toll roads requires large capital and also requires land to build the toll road. In an effort to improve the investment climate in Indonesia, aspects that require priority are the provision of infrastructure, one of which is the toll road. On the one hand the availability of infrastructure is very vital, but on the other hand the Government has a very limited budget to fulfill it. To overcome this problem, an alternative can be taken is to invite private participation in transportation infrastructure development.

Philosophically, the concept of state control rights regulated in article 33 of the 1945 Constitution is in line with the purpose of land acquisition for toll road construction. The suitability can be explained that in article 33 paragraph (3) of the 1945 Constitution of the Republic of Indonesia which contains: "Water and natural resources contained therein are controlled by State and used for the greatest prosperity of the people"

The Act Number 2 of 2012 in the "Considering" dictum, letter:

a. whereas; in the framework of realizing a just, prosperous and prosperous society based on Pancasila and the 1945 Constitution, the government needs to carry out development.

b. whereas; in order to guarantee the implementation of development in the public interest, land is needed whose procurement is carried out by promoting the principles of humanity, democracy and justice.

As a consequence of this harmony, the state has an obligation to, first, all forms of utilization of the earth, water and the results obtained therein, including the acquisition of land for toll road construction, must significantly increase the prosperity and welfare of the community, secondly, protect and guarantee all the rights of the people who contained in or on the earth and water that can be produced directly or enjoyed directly by the people, meaning that land acquisition for toll road construction must be enjoyed and beneficial for the people of Indonesia, third, preventing all actions or that will cause people to not have a chance or lose rights contained in and above the earth including water, meaning that by taking land for the benefit of toll road construction the

${ }^{1}$ Slamet Suhartono, Hukum Positif Problematik Penerapan dan Solusi Teoritiknya, DiH: Jurnal Ilmu Hukum Volume 15 Nomor 2 Agustus 2019 - Januari 2020, p. 204.

${ }^{2}$ Bentham, J., An Introduction to the Principles of Morals and Legislation, General Historical Collection, British Library, London, 1823, ed. 2005, hlm. 121-133, 218-224, look at the Fajar Sugianto, Butir-butir Pemikiran alam sejarah Intelektual dan perkembangan Akademik Hukum dan Ekonomi DIH, Jurnal Ilmu Hukum Pebruari 2014, Vol. 10, No. 19, p. 9. 
community will not lose their land rights and can live better as before the land was needed for the construction of the toll road."1

Indeed, in the application of the concept of the right to control the State (In his book, Jean-Jacques Rousseau initially stated that humans are free but do not have natural authority over each other. Initially it was referred to as the oldest form of society namely family. Children are bound to fathers as long as they need them, after not naturally but instead he does a social contract, this social contract can also be called alienation because free humans basically do not have complete freedom, as an illustration of a newborn baby being a free human but to achieve his freedom, the baby needs his mother so that the nutritional coverage is fulfilled through food and drink $)^{2}$ in the procurement of land for toll road development, it must be based on the legal objectives for justice, certainty and legal usefulness in the context of increasing the maximum prosperity of the people who are inseparable from the ideals of the Pancasila law. The ambition of the Pancasila law is contained in Article 1 (paragraph 3) as the goal of the Indonesian state of law which requires legal certainty, legal justice and the benefit of the Law. It should have become a model in the development of law within the frame of National Political Law. And the creation of Indonesian Socialism. ${ }^{3}$

Indonesian socialism contains a harmonious blend of elements of social justice and elements of Indonesia as in the principle of mutual cooperation and kinship which are the main characteristics of Indonesian personality. In carrying out social justice based on mutual cooperation and kinship, and the goal pursued and will be implemented is mutual prosperity, where there is material and spiritual prosperity in the form of abundant physical and spiritual general wealth and its distribution is evenly distributed according to the nature of each difference of the citizens.

From the normative point of view, the laws and regulations concerning the procurement of land for the benefit of toll road construction are not able to provide equitable access to the people, including customary law communities in the implementation of land acquisition, especially in providing compensation for land taken for toll road construction and unable to protect people's rights and tend to give more rights to the owners of capital and parties who have access to power, and neglects to supervise the rights that have been given to individuals and legal entities, obviously having an impact on the escalation of conflict.

\section{Conclusion}

The meaning of the right to control the state is the state's demands on individuals, communities and the state itself to exercise rights in accordance with the obligations imposed on it in the form of utilizing land, protecting and guaranteeing the rights of others and preventing actions that cause other parties to lose opportunities or land rights.

The state's right to control essentially authorizes the state to: regulate and carry out the designation, use, supply and maintenance of the earth, water, space and natural resources contained therein regulated in article 2 of UUPA Number 5 of 1960 and one form of such authority is the establishment of Law No. 2 of 2012 concerning Land Acquisition for development in the public interest.

Philosophically, the concept of state control rights regulated in article 33 of the 1945 Constitution of the Republic of Indonesia is in line with the purpose of land acquisition for toll road construction, which is used for the greatest prosperity of the people. provide equitable access to the people, including customary law communities (MHA) in the implementation of land acquisition, especially in the provision of compensation for land taken for toll road construction. The government will immediately harmonize regulations relating to the acquisition of land in the public interest as mandated by the Decree of the Republic of Indonesia Republic of Indonesia Number IX / MPR / 2001 on Agrarian Reform and Natural Resource Management and redefine the right to control the State over agrarian resources

\section{REFERENCES}

Bentham, J., An Introduction to the Principles of Morals and Legislation, General Historical Collection, British Library, London, 1823, ed. 2005, hlm. 121-133, 218-224.dalam Fajar Sugianto, Butir-butir Pemikiran alam sejarah Intelektual dan perkembangan Akademik Hukum dan Ekonomi DIH, Jurnal Ilmu Hukum Pebruari 2014, Vol. 10, No. 19.

Bakri, Muhammad, 2007, Hak Menguasai Tanah Oleh Negara, (Paradigma baru Untuk Reformasi Agraria), Ctra Media, Jakarta.

Fajar Sugianto, Efisiensi Ekonomi Sebagai Remedy Hukum, DIH, Jurnal Ilmu Hukum Pebruari 2013, Vol. 9, No.

\footnotetext{
${ }^{1}$ Winahyu, Erwiningsih, 2009, Hak Menguasai Negara Atas Tanah,. Yogyakarta, Total Media. p. 7.

2 Tomy Michael, Memaknai Pemikiran Jean-Jacques Rousseau Tentang Kehendak Umum Menciptakan Keadilan , Prosiding Seminar Nasional Multi Disiplin Ilmu \& Call For Papers Unisbank (sendi U) ke-2 tahun 2016 Kajian Multi Disiplin Ilmu dalam Pengembangan IPTEKS untuk Mewujudkan Pembangunan Nasional Semesta Berencana (PNSB) sebagai Upaya Meningkatkan Daya Saing Global, p. 531.

${ }^{3}$ Sri Setiadji, Relasi Sumber Agraria dalam perspektif Pembaruan sistem Perekonomian,, http://www.koran pagi. Net/2018/09/Relasi Sumber Agraria dalam perspekti.html, accessed 12 Agustus 2019.
} 
18

Slamet Suhartono, Hukum posotif Problematik penerapan dan Solusi Teoritiknya, DiH: Jurnal Ilmu Hukum Volume 15 Nomor 2 Agustus 2019 - Januari 2020.

SriSetiadji, Relasi Sumber Agraria dalam perspektif Pembaruan sistem Perekonomian,, http://www.koran pagi. Net/2018/09/Relasi Sumber Agraria dalam perspekti.html, accessed 12 Agustus 2019.

, Hak Menguasai dan Pengelolaan SDA dalam Perspektif Sistm Perekonomian, Opini, Radjawarta, Minggu 24 September 2018.

Sumardjono, Maria A, Kebijakan Pertanahan antara Regulasi dan Implementasi, Edisi revisi, cetakan ke tiga, Penerbit buku Kompas, Jakarta, 2005.

Syofyan Hadi, Hukum Posotif dan The Living Law(Eksistensi danKeberlakuannya dalam Masyarakat) DiH Jurnal Ilmu Hukum Volume 13 Nomor 26 Agustus 2017.

Tine Suartina, Analisis Hukum Pada Kebijakan Kebjakan Pembebasan Tanah Untuk Kepentingan Umum di Indonesia, Jurnal Masyarakat \& Budaya, Volume 10 No. 1 Tahun 2008.

Tomy Michael, Memaknai Pemikiran Jean-Jacques Rousseau Tentang Kehendak Umum Menciptakan Keadilan, Prosiding Seminar Nasional Multi Disiplin Ilmu \& Call For Papers Unisbank (sendi_U) ke-2 tahun 2016 Kajian Multi Disiplin Ilmu dalam Pengembangan IPTEKS untuk Mewujudkan Pembangunan Nasional Semesta Berencana (PNSB) sebagai Upaya Meningkatkan Daya Saing Global.

Winahyu, Erwiningsih, 2009, Hak Menguasai Negara Atas Tanah,. Yogyakarta, Total Media.

Undang-Undang Dasar Negara Republik Indonesia 1945.

Undang-Undang Nomor 2 Tahun 2012 Tentang Pengadaan Tanah Bagi Pembangunan Untuk Kepentingan Umum. 